\title{
Foraging behavioral of Phylloscartes ventralis (Aves, Tyrannidae) in native and planted forests of southern Brazil
}

\author{
André de Mendonça-Lima \& Sandra M. Hartz \\ Programa de Pós-graduação em Ecologia, Laboratório de Ecologia de Populações e Comunidades, Universidade Federal do Rio Grande do Sul., Av. Bento Gonçalves 9500, Prédio 43411/209, \\ 91501-970 Porto Alegre, RS, Brazil. (mendoncalima@hotmail.com; corresponding author: sandra.hartz@ufrgs.br)
}

\begin{abstract}
Few studies have related the effects of silviculture practices to the behavior of bird species in the Neotropics. The present study examined the foraging behavior of Phylloscartes ventralis (Temminck, 1824) in a native forest and in silviculture areas of Pinus elliotti and Araucaria angustifolia with different structures and ages. We tested two general hypotheses: (1) areas of commercial forest plantation change the foraging behavior of $P$. ventralis in relation to native forest, and (2) the foraging behavior of $P$. ventralis in silviculture areas with understories (complex structures) is different from its behavior in areas without understory. The results showed that $P$. ventralis changed its foraging behavior depending on the type of forest, and on the presence of an understory in silviculture areas. Main changes involved the height and angle of substrate where the prey was captured. Phylloscartes ventralis showed the same set of attack maneuvers, with more maneuvers type in young Pinus planted without understory. The frequency of use of attack maneuvers was more similar in areas of silviculture with understory and in the native forest. The results highlight the importance of an understory structure and the utilization of native plant species in silviculture practices, to the foraging behavior of native bird species.
\end{abstract}

KEYWORDS. Mottle-cheeked Tyrannulet, attack maneuvers, Araucaria angustifolia, Pinus elliotti, habitat structure.

RESUMO. Comportamento de forrageio de Phylloscartes ventralis (Aves, Tyrannidae) em florestas nativas e plantadas no sul do Brasil. Poucos estudos têm relacionado os efeitos que práticas silviculturais exercem sobre o comportamento de aves neotropicais. O presente estudo analisou o comportamento de forrageio de Phylloscartes ventralis (Temminck, 1824) em uma floresta nativa e em áreas de silvicultura de Pinus elliottii e Araucaria angustifolia com diferentes estruturas e idades. Foram testadas duas hipóteses gerais: (1) áreas de plantio comercial alteram o comportamento e forrageio de $P$. ventralis em relação à mata nativa e (2) o comportamento de forrageio de $P$. ventralis em áreas de silvicultura com sub-bosque (estruturalmente mais complexas) é diferente do registrado em áreas sem sub-bosque. Os resultados demonstram que $P$. ventralis alterou seu comportamento de forrageio dependendo do tipo de floresta e da presença de sub-bosque em áreas de silvicultura. As principais mudanças envolvem a altura e o ângulo de substrato onde a presa foi capturada. Phylloscartes ventralis exibiu o mesmo grupo de manobras de ataque a presas, com um maior número de tipos de manobras em plantações jovens de Pinus sem sub-bosque. A frequência de uso de manobras de ataque a presas foi mais similar em áreas de silvicultura com sub-bosque e na floresta nativa. Os resultados destacam a importância do sub-bosque e da utilização de espécies nativas em práticas silviculturais para a manutenção do comportamento de forrageio de uma espécie de ave nativa.

PALAVRAS-CHAVE. Borboletinha-do-mato, manobras de ataque, Araucaria angustifolia, Pinus elliottii, estrutura de hábitat.

The structure of the habitat is an important factor affecting the foraging behavior of animal species in different areas (MAcArthur \& PianKa, 1966; MoERmond, 1979; Maurer \& Whitmore, 1981; Sabo \& Holmes, 1983; WhELAN, 2001). Alterations in the habitat structure can change the quantity and quality of available resources. Therefore, in altered habitats, species are forced to change their foraging mode, or they may be replaced by other species (GruBB, 1979; Kusch et al., 2004). For instance, plant species with different foliage structures can affect bird behavior, which in turn changes the habitat availability and the resource exploitation (FranzeB, 1978; Holmes \& RoBINSON, 1988). Among vertebrates, the foraging behavior of insectivorous birds is particularly well studied, mainly in Europe and North America (Holmes \& Robinson, 1981; WhELAN, 2001). Although knowledge of the foraging behavior of bird species is a key question for successful management of populations, communities and ecosystems (LEŠO \& KROPIL, 2007), the use of different tree species by insectivorous birds in tropical habitats has received little attention (GREENBERG \& BichiER, 2005).

Studies of the foraging behavior of birds in the
Neotropics are usually done in forest ecosystems (MARINI \& Cavalcanti, 1993; Latta \& Wunderle, 1998; Soares \& Anjos, 1999; Mendonça-Lima et al., 2004; Gabriel \& Pizo, 2005; Greenberg \& Bichier, 2005, among others) and studies in silviculture areas or commercial forest plantations are scarce, compared with native areas (WUNDERLE \& Latta, 1998; Pomara et al., 2003; Dietsch et al., 2007). Assessments of foraging strategy patterns can help in the understanding of population and community dynamics, because these patterns can influence the fluctuations of abundance and occurrence of a species in a particular habitat (HOLT \& KRIMBELL, 2007; KOTLER \& BROWN, 2007). Therefore, it is important to study the foraging behavior of species in silviculture areas compared with native areas, because tree plantations markedly alter the habitat, and these changes may lead to the local extinction of some species, whereas others may be able to colonize the altered habitats.

The New World family Tyrannidae is one of the most representative bird taxa and is among the most numerous in the world (FitZPATrick, 1980, 2004; Sick, 1997). The forest-dwelling species of this family occupy all forest 
vertical strata (Sick, 1997). Less diverse at the ground layer, they increase in richness toward the upper layer of the forests (TRAYlor \& FitzPATRICK, 1982; SicK, 1997). The Mottle-cheeked Tyrannulet (Phylloscartes ventralis) is a common inhabitant of forests in south and southeast Brazil (BeLton, 1985; RosÁrio, 1996; SicK, 1997). It also occurs in Argentina, Uruguay and Paraguay, and in a disjunct area from northwest Argentina to Bolivia and Peru (RidgelY \& TUDOR, 2009). The species is typically found in the middle to upper layers of forests and woodlands (BELTON, 1985; Sick, 1997). The foraging maneuver commonly used by Mottle-cheeked Tyrannulet is the Sally-strike, a very stereotyped maneuver and mainly characteristic of the small-bodied tyrant flycatchers (FitZPATRICK, 1980; Remsen \& RoBinson, 1990).

Assessment of the patterns of foraging behavior of native bird species in the managed and native forests of the Araucaria forest ecosystem is particularly important to fill a gap in knowledge about the impact of habitat change on bird populations in this region. Therefore, in this study we evaluated whether there are differences in the foraging behavior of Mottle-cheeked Tyrannulets associated with the habitat structure of planted and native forests. These forests differ in their understory structure (MENDONÇA-LimA et al., 2014), when it is present (depending on the type of management) and this can lead to changes in foraging behavior of insectivorous birds. We specifically tested the hypothesis that the frequency of foraging behavior variables including prey-attack maneuvers, the type and angle of substrate, the height at which foraging is conducted, and the horizontal position where the attack was directed were different in native and managed forests.

\section{MATERIAL AND METHODS}

Study area. The study was carried out in stands of commercial plantations of Pinus elliottii and Araucaria angustifolia, as well as in areas of native forests on a commercial tree farm located in the Campo Belo do Sul municipality, southern Brazil (1,000 m a.s.1.; $28^{\circ} 00^{\prime} \mathrm{S}$, $50^{\circ} 49^{\prime} \mathrm{W}$ ). The tree farm has an area of $14,200 \mathrm{ha}$, of which 6,300 ha is part of a sustainable-use conservation unit. The remaining area is planted with different-aged stands of Pinus spp. The climate is typical of the southern Brazilian highlands, with cool summers, no dry season, and frequent severe frosts in winter (Köppen $\mathrm{Cfb}$ classification). The mean annual temperature is $16^{\circ} \mathrm{C}$ (SANTA CATARINA, 1986).

The characteristic regional native vegetation is the Araucaria forest, which occurs mainly between 400 and 1,000 $\mathrm{m}$ a.s.l. along watercourses, valleys, hillsides, and grasslands on the plateau (KLEIN, 1978; IBGE, 1992). The presence of $A$. angustifolia comprises the main physiognomy; these trees occur in continuous forest habitats as well as in patches embedded in the plateau grasslands (RАмBO, 1951). Besides this species there are several genera of laurel trees in this forest, such as Ocotea and Nectandra, and another native genera of conifer
(Podocarpus) (CÂMARA, 2003).

The sampling was performed in a native forest, and in commercial forest stands of $P$. elliotti and A. angustifolia. The $P$. elliotti plantations were distinguished by age and by the presence of an understory: (1) 7-year-old plantations without understory (MP), (2) 25-year-old plantations without understory (OP), and (3) 27-year old plantations with understory (PS). The 30-year-old $A$. angustifolia plantation had an understory too (AP). All forest plantation areas were contiguous (edge area) with the native forest (NF). The native forest was located on hillsides and in the valley of the region, and had a dense understory. The mean distance between the areas was $8 \mathrm{~km}$, and between each area in the same vegetation type was $2 \mathrm{~km}$. Four sampling sites were marked, within each of five different forest treatments (three Pinus plantations, the Araucaria plantation and the native forest). The sampling sites were located at least $100 \mathrm{~m}$ from any edge area, and were $500 \times 100 \mathrm{~m}$ wide. The overstory of each plantation was uniform in height; however, there were differences between the treatments: the 27-year old $P$. elliottii plantations with understory and 25-year-old P. elliottii plantations without understory had the highest canopy heights ( $25 \mathrm{~m}$ and $23 \mathrm{~m}$ respectively); followed by native forest (21.9 m), 7-year-old P. elliottii plantations without understory $(16 \mathrm{~m})$, and 30 -year-old $A$. angustifolia plantations with understory (13 m). Understory composition and diversity of planted and native forests are described in Mendonça-Lima et al. (2014).

Data collection. Bird behavior was observed during the breeding season of spring 2008 (between 3-10 October) and 2009 (between 2 October-11 November), starting 30 min after sunrise; the total sampling effort was $199.74 \mathrm{hr}$. We used the focal-animal sampling (ALtmann, 1974) with modifications (Marini \& CaValcanti, 1993; MendonçALiMA et al., 2004). Individuals of Mottle-cheeked Tyrannulet were identified and observed from a distance $>7 \mathrm{~m}$, using binoculars. After the first sighting of an individual, the data recording started when it first attacked the prey, always taking care to not disturb the bird during foraging. When this was perceptible (e.g., attention directed to the observer, more frequent and nervous vocalizations), the distance of observation was increased and the data recording was resumed after the bird resumed its usual behavior. Two or more observations of the same individual were considered valid only when they were separated by a minimum interval of $5 \mathrm{~min}$, to assure independence of observations.

We recorded data on the following behavior variables: position of the individual in relation to the ground (height), attack maneuvers to prey (REMSEN \& Robinson, 1990), the substrate type where the attack occurred, the substrate angle, and the horizontal position in relation to the main axis of the focus tree. The position of the birds in relation to the ground was defined by visual estimation at 2-m intervals. The foraging substrate was classified as: green and dry leaves (included Pinus and Araucaria needles), branch with a maximum diameter of $1 \mathrm{~cm}$, branch with a diameter thicker than $1 \mathrm{~cm}$, and air. The substrate 
angle was divided into vertical (equal to or more than $45^{\circ}$ in relation to the ground) and horizontal (less than $45^{\circ}$ in relation to the ground) (MARINI \& CAVALCANTI, 1993). When the individual bird attacked a prey on leaves or branches, the horizontal position in relation to the central axis of the focal tree was divided into three equal parts and defined as proximal, medial or distal (MACARTHUR, 1958).

Statistical analyses. We evaluated the sampling effort by the analysis of cumulative estimates of prey attackmaneuver frequencies. In order to analyze the patterns of foraging behavior, we constructed a frequency matrix of sampling units and various classes of attack maneuvers, heights, foraging substrates, angles, and the position in relation to the central axis of a focal tree. Therefore, we consider a sampling unit within each treatment was composed by the frequency of set of six consecutive records of behavioral variables. The variation in the composition of behavioral-variable frequencies between forest treatments was analyzed by performing a Permanova based on a Gower or Euclidean distance (for heights analysis) dissimilarity matrix between sampling units. The age of the stands and the presence of understory were used as blocks in the analysis. The comparison between groups of sampling units belonging to the forest treatments was based on a sum of squares between groups as test criterion $-Q b$ statistics (MANly, 1991, 1994; Pillar \& Orlóci, 1996). The results are interpreted similarly to those in an ANOVA table. Significant differences between treatments were based on a $\mathrm{P}$-value $<=0.05$. A Principal Coordinates Analysis (PCoA) was carried out (using chord distance) to visualize the pattern of distribution of foraging behavioral variables within treatments. All data were analyzed in the MULTIV 2.63 statistical package (PILlar, 2006).

\section{RESULTS}

A total of 265 observations of Mottle-cheeked Tyrannulet foraging behavior were made during the study. The highest frequency of observations occurred in 30-yearold $A$. angustifolia plantation with understory (1.93 obs./ hr), followed by 27 -year old $P$. elliottii plantations with understory (1.55), native forest (1.51), 7-year-old P. elliottii plantations without understory (1.25), and 25-year-old $P$. elliottii plantations without understory (0.98). Therefore, the treatments without understory showed the lowest frequency of observations.

The mean height of foraging differed between areas $(\mathrm{P}=0.001)$ and was smaller in the Pinus plantations with understory (Fig. 1). Mean height was $18.95 \mathrm{~m}$ in 25 -year-old P. elliottii plantations without understory $(\mathrm{SD}=2.99)$ and $12.01 \mathrm{~m}(\mathrm{SD}=2.29)$ in 7-year-old $P$. elliottii plantations without understory, while in plantations with understory the mean height was $4.36 \mathrm{~m}(\mathrm{SD}=2.65)$ in 27 -year old P. elliottii plantations with understory and around $9.00 \mathrm{~m}$ $(\mathrm{SD}=2.46)$ in 30-year-old $A$. angustifolia plantation with understory and in the native forest (Fig. 1).

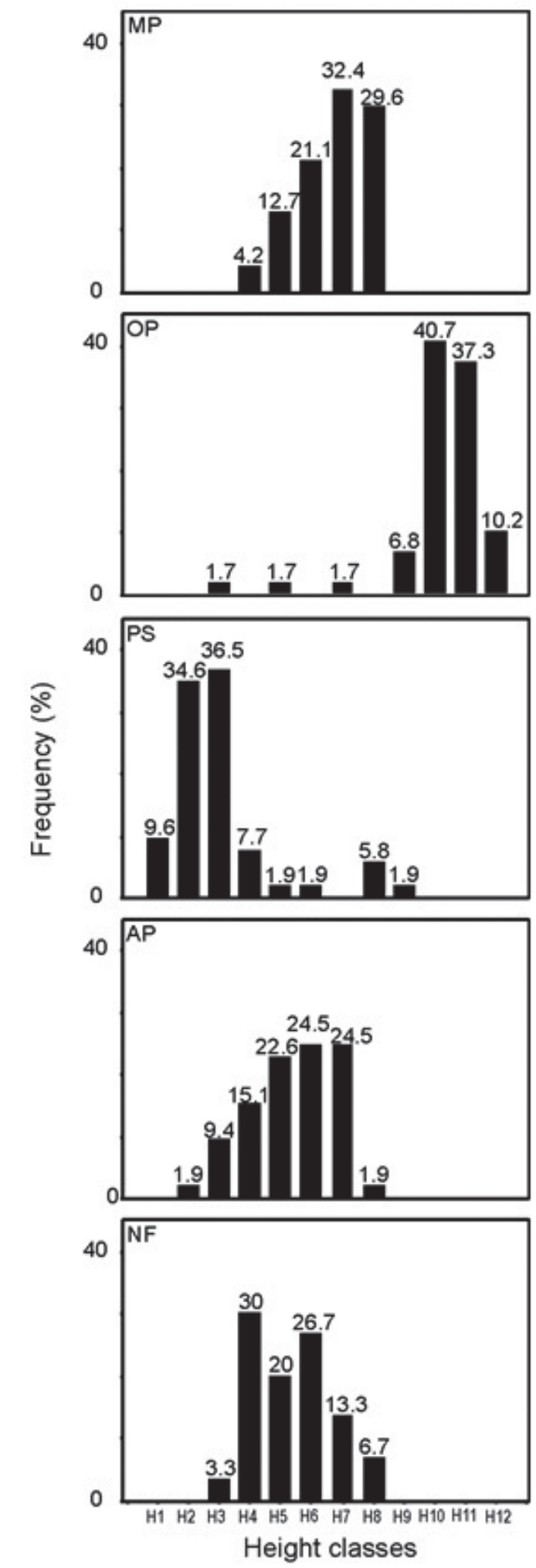

Fig. 1. Distribution of foraging-height class frequencies of Mottle-cheeked Tyrannulet in native and plantation forests. Legends: NF (native forest more than 40 years old, $\mathrm{n}=30$ ), AP (30-year-old plantations of Araucaria angustifolia with understory, $\mathrm{n}=53)$, PS (25-year-old plantations of Pinus elliotti without understory, $\mathrm{n}=52)$, OP (25-year-old plantations of $P$. elliotti without understory, $\mathrm{n}=59)$, MP (7-year-old plantations of P. elliotti without understory, $\mathrm{n}=71$ ), $\mathrm{H} 1$ (height class $0-2 \mathrm{~m}$ ), H2 (class 2-4 m), H3 (class 4-6 m), H4 (class 6-8 m), H5 (class 8-10 m), H6 (class 10-12 m), H7 (class 12-14 m), H8 (class 14-16 m), H9 (class 16-18 m), H10 (class 18-20 m), H11 (class 20-22 m), H12 (class 22-24 m). 
Mottle-cheeked Tyrannulet used a wider range of attack maneuvers in 7-year-old $P$. elliottii plantations without understory compared to the other treatments (Fig. 2); however, there was no significant difference between the areas $(\mathrm{P}=0.354)$. Taking all treatments into account, there was a higher frequency of maneuvers that involved flight (Fig. 2). As a result, the attack maneuvers oriented to prey away from the bird's perch were more frequent for all treatments.

The treatments did not differ regarding the substrates to which foraging maneuvers were oriented $(\mathrm{P}=0.16)$. There was a high frequency of attacks directed to green leaves in all areas and the species again used all the substrates in Pinus plantations without understory (Fig. 3). The angle of substrate where prey was attacked was horizontal in native forest and forest plantations with understory, while this proportion decreased in plantations without understory $(P=0.04$, Fig. 4). The frequency of maneuvers directed to proximal spots was higher in native forest, while the maneuvers were more often directed to distal spots in 30-year-old $A$. angustifolia plantation with understory and in 27-year old P. elliottii plantations with understory (Fig. 5), but there was no significant difference between the areas $(\mathrm{P}=0.61)$.

Considering all the foraging behavior variables the dispersion diagram for the PCoA clearly showed differences, where the frequency of occurrence of height of foraging, prey-attack behavior, and substrate directions were important to characterize the foraging behavior among treatments (Fig. 6). Planted forests with understory (Pinus and Araucaria) were close to the native forest in the first axis of the ordination. The second axis of ordination segregated the 25-year-old plantations of Pinus elliotti without understory from other ones.

\section{DISCUSSION}

The morphology of a bird restricts the kind of foraging maneuvers it can effectively utilize during prey-attacks. Therefore, foraging maneuvers tend to be conservative compared to other behaviors (e.g., foraging height), which are not linked to the bird's shape and structure (Hutto, 1981; Martin \& KarR, 1990). Consequently, the foraging tactics and the morphology combined with the habitat structure indicate which species can be found in a certain habitat (Holmes \& ROBINSON, 1988; ForSTMEIER \& KeßLER, 2001). Mottle-cheeked Tyrannulet altered significantly the height and angle of the maneuvers between native and planted forests, and changed the frequency of use of prey-attack maneuvers. This was apparent from the ordination scatterplot, where the maneuver behaviors correlated with the first axis, which described the differences in the foraging behavior among the treatments (sally-pounce and vertical substrate in positive axis versus sally-hover and horizontal substrate in negative axis). Bird species using flight maneuvers seem not to alter the foraging tactic between stands of different tree species; therefore, this

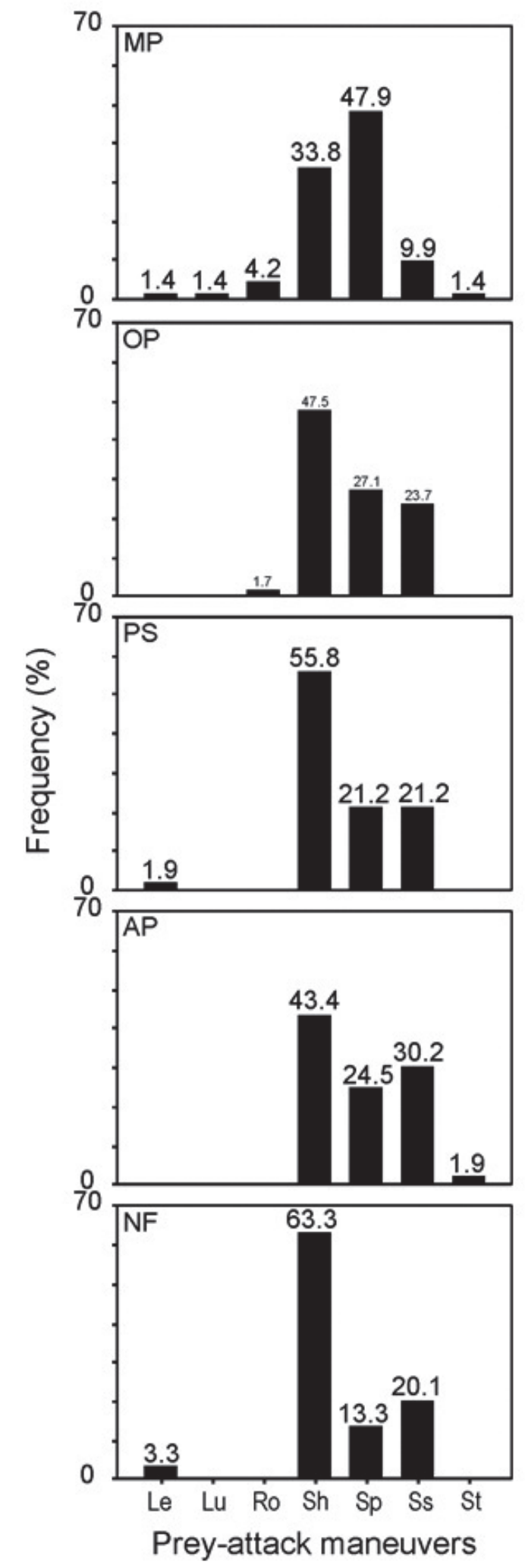

Fig. 2. Distribution of prey-attack maneuver frequencies in native and plantation forests. Legends: NF (native forest more than 40 years old, $n=$ 30), AP (30-year-old plantations of Araucaria angustifolia with understory, $\mathrm{n}=53)$, PS (25-year-old plantations of Pinus elliotti without understory, $\mathrm{n}=52)$, OP (25-year-old plantations of $P$. elliotti without understory, $\mathrm{n}$ = 59), MP (7-year-old plantations of $P$. elliotti without understory, $\mathrm{n}=$ 71), Le (leap), Lu (lunge), Ro (reach-out), Sh (sally-hover), Sp (sallypounce), Ss (sally-strike), St (sally-stall). 

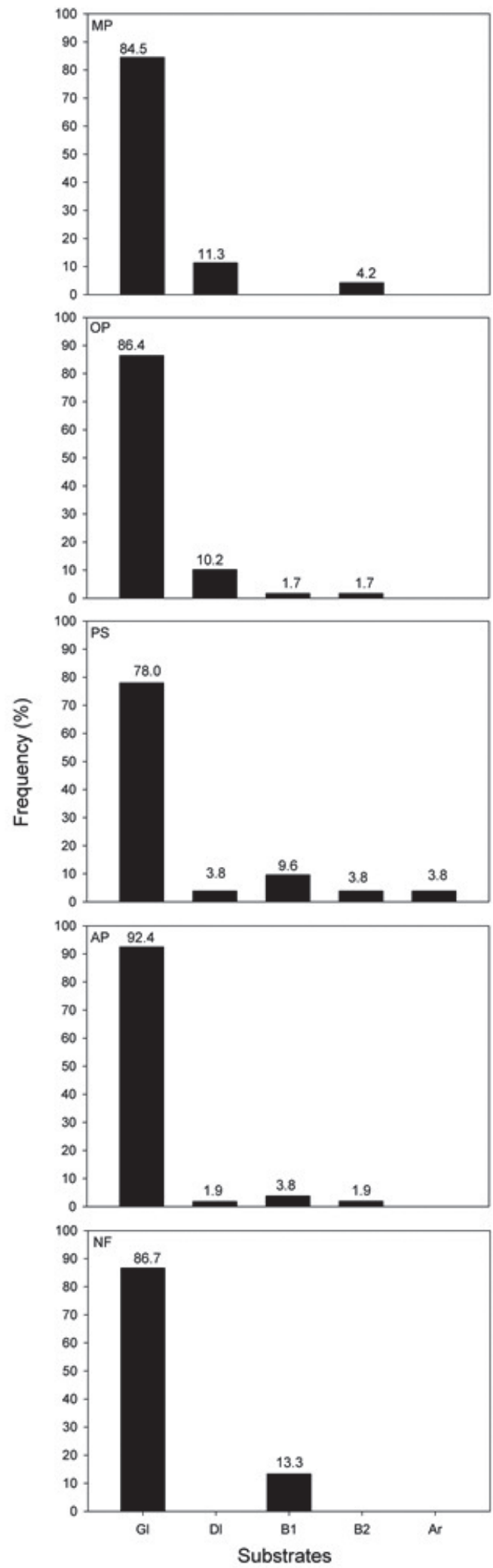

Fig. 3. Distribution of frequencies of the substrates used during the foraging in native and plantation forests. Legends: $N F$ (native forest more than 40 years old, $\mathrm{n}=30$ ), AP (30-year-old plantations of Araucaria angustifolia with understory, $\mathrm{n}=53)$, PS (25-year-old plantations of Pinus elliotti without understory, $\mathrm{n}=52)$, OP (25-year-old plantations of $P$. elliotti without understory, $\mathrm{n}=59)$, MP (7-year-old plantations of P. elliotti without understory, $\mathrm{n}=71$ ), $\mathrm{Gl}$ (green leaves), Dl (dry leaves), B1 (branches $<1 \mathrm{~cm})$, B2 (branches $>1 \mathrm{~cm}$ ), Ar (Air).

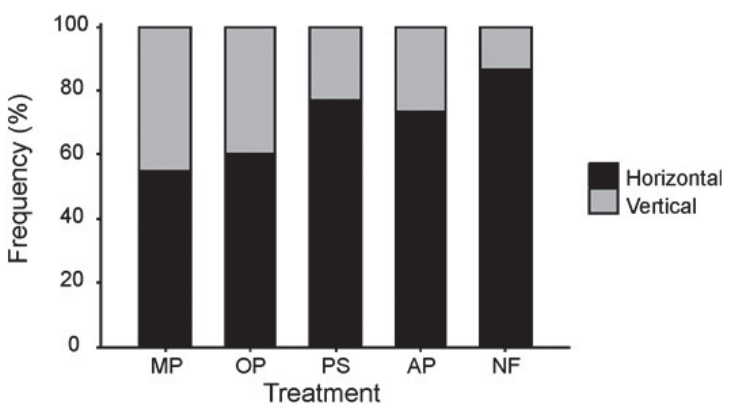

Fig. 4. Distribution of frequencies of the angles used during the foraging in native and plantation forests. Legends: NF (native forest more than 40 years old, $\mathrm{n}=30)$, AP (30-year-old plantations of Araucaria angustifolia with understory, $\mathrm{n}=53)$, PS (25-year-old plantations of Pinus elliotti without understory, $\mathrm{n}=52)$, OP (25-year-old plantations of $P$. elliotti without understory, $\mathrm{n}=58)$, MP (7-year-old plantations of $P$. elliotti without understory, $\mathrm{n}=71$ ).

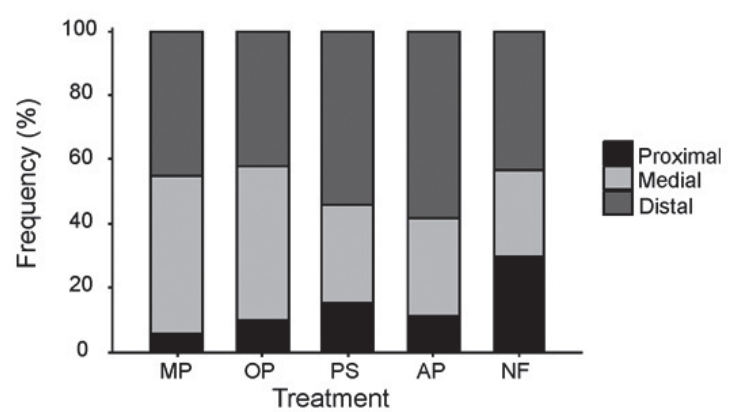

Fig. 5. Distribution of the frequencies of the positions where prey-attacks occurred during foraging in native and plantation forests. Legends: NF (native forest more than 40 years old, $\mathrm{n}=30$ ), AP (30-year-old plantations of Araucaria angustifolia with understory, $\mathrm{n}=53)$, PS (25-year-old plantations of Pinus elliotti with understory, $\mathrm{n}=52)$, OP (25-year-old plantations of $P$. elliotti without understory, $\mathrm{n}=59)$, MP (7-year-old plantations of $P$. elliotti without understory, $\mathrm{n}=71$ ).

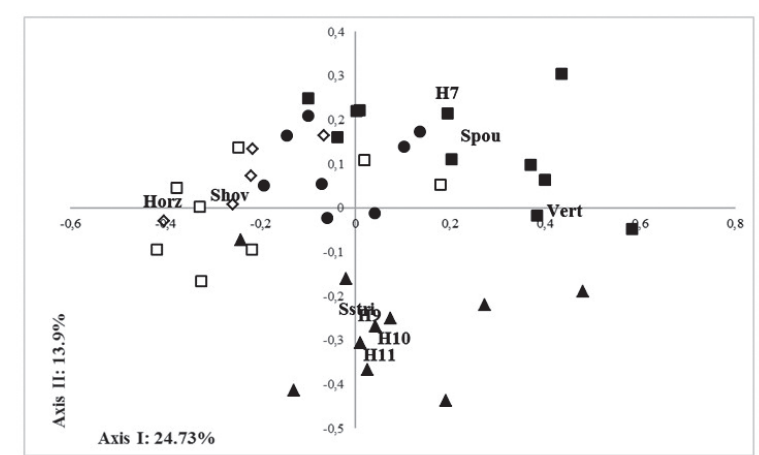

Fig. 6. Ordination diagram of the first and second axes of the PCoA based on the frequencies of foraging behaviors of Mottle-cheeked Tyrannulet in native and plantation forests. The foraging behavior variables represented in the diagram showed higher correlations with either one or both axes $(r>0.5)$. Legends: filled triangles $=25$-year-old plantations of Pinus elliotti without understory, filled circles $=30$-year-old plantations of Araucaria angustifolia with understory, open diamond = native forest more than 40 years old, filled squares $=7$-year-old plantations of $P$. elliotti without understory, open squares $=25$-year-old plantations of $P$. elliotti with understory. H7-11 (foraging-height class), Spou (sally-pounce), Shov (sally-hover), Sstri (sally-strike), Hor (horizontal substrate), and Ver (vertical substrate). 
strategy could function as a tactic to reduce the effects of habitat structure on the foraging behavior (Holmes \& Robinson, 1981).

Despite substrate did not differ in the areas, in planted forests most maneuvers were made in Pinus and Araucaria needles, compared with angiosperms in native forest. Hence, we found that the major changes Mottlecheeked Tyrannulet made to occupy the different habitats were related to the structure of the vegetation (substrate type, horizontal location, and height) and to the frequency of occurrence of certain aerial maneuvers used in its native habitat. This plasticity enabled Mottle-cheeked Tyrannulet to occupy all the forests investigated.

The differences in the structure and composition of plants among the forest stands (MENDONÇA-LimA et al., 2014) can alter the distribution of resources, which may be an important factor influencing the observed changes in the bird's foraging behavior (MAURER \& WHITMORE, 1981). Differences in the structure of native and managed forests may affect the distribution and density of bird prey species (Franzeb, 1983; Parrish, 1995; Greenberg \& Bichier, 2005). The foraging behavior encompasses diverse phases, among which are the search to locate the food, and the prey-attack to capture the food (REMSEN \& RoBinson, 1990), which can be changed by the location of the resource. In this study, Mottle-cheeked Tyrannulet changed the mode of prey capture, although it could have changed the mode of prey searching as well. Previous studies showed that the distribution and density of foliage influenced the foodsearching tactics of species that usually attack the prey by flight (Robinson \& Holmes, 1984; Holmes \& Recher, 1986).

In our study, the frequency of behavior observations was higher in the native forest and in the forest plantations with understory, which may be related to resource availability or to differences in species abundance. Some species show a positive correlation between the attack rate and food availability (Johnson, 2000; Lyons, 2005). Two hypotheses related to resource availability may explain this general pattern of habitat use: (1) the species may use a wide variety of prey in the different habitats, and (2) high productivity in the breeding season can force the individuals to utilize sub-optimal habitats (RAPPOLE, 1996). These two explanations held for Mottle-cheeked Tyrannulet in the areas of commercial plantations, where this generalist species can benefit from a wide variety of prey, occupying habitats with fewer resources, but also with fewer competitors. This may explain the use of a larger set of maneuvers and higher heights in Pinus without understory by the species. In shaded-coffee farms, JEDLICKA et al. (2006) found shift in the behavioral foraging (mainly in height) by Rufous-capped Warbler (Basileuterus rufifrons Swainson, 1838) to avoid seasonal competition with migrant species.

The habitat structure of forest monocultures is simpler than the native forests (ADAмík et al., 2003).
The restrictions imposed by the vegetation structure and prey abundance determine the opportunities for foraging. The foraging characteristics of bird species that enable successful exploitation of resources in a particular habitat can be affected by these structural variables (RoBINSON \& Holmes, 1982). The Mottle-cheeked Tyrannulet occurs in the medium/high forest strata, and demonstrated the capacity to adapt to habitats with different structures. Therefore, the plasticity of its foraging behavior enabled this flycatcher to occupy the commercial forest stands. Mottle-cheeked Tyrannulet changed its height of foraging in plantation stands. This alteration may be common in a species that uses the middle forest stratum, because birds foraging in this stratum use a greater range of heights compared to species foraging in the canopy (WALTHER, 2002). Bird species using flight maneuvers tend to take advantage of different opportunities for foraging, compared to species that use other forms of prey capture (MAURER \& Whitmore, 1981). Therefore, it is suggested that the capacity to capture prey in the different substrates within the treatments was possible due to the plasticity of foraging behavior, by altering the frequencies of maneuvers used by Mottle-cheeked Tyrannulet in the different habitats.

The present study showed alterations in the foraging behavior of Mottle-cheeked Tyrannulet among different forest habitats. The change in the behavior of Mottlecheeked Tyrannulet among plantations with different plant species (one native and one exotic) was important, wherein planted Araucaria was more similar to native forest. This result emphasizes the importance of using native plant species in silviculture systems, which reduces the negative impact on the local fauna. Studies of bird assemblages confirm this statement (ZuRITA et al., 2006; Volpato et al., 2010). The presence of the understory in exotic plantations allowed Mottle-cheeked Tyrannulet to use the different foraging substrates, showing differences in the height, angle and frequency of utilization of attack maneuvers between the Pinus plantations. The observations of the foraging behavior in Pinus with and without understory indicated that vegetation structure may be determining the presence of Mottle-cheeked Tyrannulet in the plantations. Then, the dominant tree in the stands may play an important role in determining the bird species occurring in this type of habitat (e.g., GREENBERG \& BiCHIER, 2005). Commercial plantations have expanded greatly in recent years. Hence, there is a need to study the effects of this kind of system on animal populations and communities, in order to suggest management practices to mitigate possible deleterious effects. The findings of this study highlighted the importance of the presence of an understory and the native tree species A. angustifolia in commercial plantations to the foraging behavior of the species studied. Proper management of this forest habitat, with maintenance of understory and planting native species, may provide an important commercial alternative, and may also help in the conservation of the fauna in silviculture areas contiguous to native forests. 
Acknowledgements. We thank the $\mathrm{CNPq}$ for a productivity research grant received by SMH (306816/2010-5) and CAPES the doctorate scholarship received by AML. We are grateful for the logistical support of the staff of the Fazenda Florestal Gateados, especially Valdir Dhiel, Mário Dobner, and Maite Ribeiro. Andreas Kindel, Luiz dos Anjos, and Paulo de Tarso Zuquim Antas made valuable suggestions during the manuscript preparation.

\section{REFERENCES}

AdAmí,, P.; KoRnan, M. \& VoJTEK, J. 2003. The effect of habitat structure on guild patterns and the foraging strategies of insectivorous birds in forests. Biologia 58:275-285.

Altmann, J. 1974. Observation study of behavior: sampling, methods. Behaviour 49:227-267.

Belton, W. 1985. Birds of Rio Grande do Sul, Brazil. Part 2. Formicariidae through Corvidae. Bulletin of the American Museum of Natural History 180:1-242.

CÂmARA, I. C. 2003. Brief history conservation in the Atlantic Forest. In: Galindo-Leal, C. \& CÂmara, I. G. eds. The Atlantic Forest of South America: biodiversity status, threats, and outlook. Washington, Conservation International, Island Press, p. 31-42.

Dietsch, T. V.; Perfecto, I. \& Greenberg, R. 2007. Avian foraging behavior in two different types of coffee agroecosystem in Chiapas, Mexico. Biotropica 39:232-240.

FitzPATRick, J. W. 1980. Foraging behavior of Neotropical Tyrant Flycatchers. Condor 82:43-57.

. 2004. Family Tyrannidae (Tyrant-flycatchers). In: Del Hoyo, J.; Elliott, A. \& Christie, D. A. eds. Handbook of the birds of the world. Vol. 9. Cotingas to Pipits and Wagtails. Barcelona, Lynx Edicions, p. 170-462.

Forstmeier, W. \& KeßLer, A. 2001. Morphology and foraging behavior of Siberian Phylloscopus warblers. Journal of Avian Biology 32:127-138.

FranzeB, K. E. 1978. Tree species used by birds in logged and unlogged Mixed-coniferous Forests. The Wilson Bulletin 90:221-238.

1983. A comparison of avian foraging behavior in unlogged and logged Mixed-coniferous Forest. The Wilson Bulletin 96:60-76.

Gabriel, V. A. \& Pizo, M. A. 2005. Foraging behavior of tyrant flycatchers (Aves, Tyrannidae) in Brazil. Revista Brasileira de Zoologia 22:1072-1077.

GREENBERG, R. \& Bichier, P. 2005. Determinants of tree species preference of birds in Oak-Acacia woodlands of Central America. Journal of Tropical Ecology 21:57-66.

GRUBB, T. C. 1979. Factors controlling foraging strategies of insectivorous birds. In: Dickson, J. G.; CONNOR, R. N.; FleET, R. R.; JACKSON, J. A. \& KROLL, J. C. eds. The role of insectivorous birds in forest ecosystems. London, Academic Press, p. 119-135.

Holmes, R. T. \& Recher, H. F. 1986. Search tactics of insectivorous birds foraging in an Australian eucalypt forest. Auk 103:515-530.

Holmes, R. T. \& Robinson, S. K. 1981. Tree species preferences of foraging insectivorous birds in a northern Hardwoods Forest. Oecologia 48:31-35.

1988. Spatial patterns, foraging tactics, and diets of groundforaging birds in a northern Hardwoods Forest. The Wilson Bulletin 100:377-394.

Holt, R. D. \& Krimbell, T. 2007. Foraging and population dynamics. In: Stephens, D. W.; Brown, J. S. \& Ydenberg, R. C. eds. Foraging: behavior and ecology. Chicago, The Chicago University Press, $p$. 365-396.

Hutto, R. L. 1981. Seasonal variation in foraging behavior of some migratory western wood warblers. Auk 98:765-777.

IBGE. 1992. Manual técnico da vegetação brasileira. Série manuais técnicos em geociências. Rio de Janeiro, IBGE. 92p.

Jedlicka, J.; Greenberg, R.; Perfecto, I.; Philpott, S. \& Dietsch, T. 2006. Seasonal shift in the foraging niche of a tropical avian resident: resource competition at work? Journal of Tropical Ecology 22:385395.

JoHNSON, M. D. 2000. Evaluation of an arthropod sampling technique for measuring food availability for forest insectivorous birds. Journal of Field Ornithology 71:88-109.
KLEIN, R. M. 1978. Mapa fitogeográfico do estado de Santa Catarina: resenha descritiva da cobertura original. Itajaí, SUDESUL, FATMA e Herbário Barbosa Rodrigues.

Kotler, B. P. \& Brown, J. S. 2007. Community ecology. In: Stephens, D. W.; Brown, J. S. \& Ydenberg, R. C. eds. Foraging: behavior and ecology. Chicago, The Chicago University Press, p. 397-476.

Kusch, J.; Weber, C.; Idelberger, S. \& Koob, T. 2004. Foraging habitat preferences of bats in relation to food supply and spatial vegetation structures in a western European low mountain range forest. Folia Zoologica 53:113-128.

Latta, S. C. \& Wunderle JR., J. M. 1998. The assemblage of birds foraging in native West Indian pine (Pinus occidentalis) forests of the Dominican Republic during the nonbreeding season. Biotropica 30:645-656.

LEŠo, P. \& KROPIL, R. 2007. A comparison of three different approaches for the classification of bird foraging guilds: an effect of leaf phenophase. Folia Zoologica 56:51-70.

Lyons, J. E. 2005. Habitat-specific foraging of Prothonotary Warblers: deducing habitat quality. Condor 107:41-49.

MacArthur, R. H. 1958. Population ecology of some warblers of northeastern coniferous forests. Ecology 39:599-619.

MacArthur, R. H. \& PianKa, E. R. 1966. On optimal use of a patchy environment. American Naturalist 100:603-609.

Manly, B. F. J. 1991. Randomisation and Monte Carlo methods in biology. London, Chapman and Hall. 281p.

. 1994. Multivariate statistical methods. London, Chapman and Hall. 232p.

Marini, M. A. \& CAVALCANTI, R. B. 1993. Habitat and foraging substrate use of three Basileuterus warblers from central Brazil. Ornitologia Neotropical 2:69-76.

Martin, T. E. \& KARR, J. R. 1990. Behavioral plasticity of foraging maneuvers of migratory Warblers: multiple selection periods for niches? Studies in Avian Biology 13:353-359.

Maurer, B. A. \& WhitMore, R. C. 1981. Foraging of five bird species in two forests with different vegetation structure. The Wilson Bulletin 93:478-490.

MendonçA-Lima, A.; Hartz, S. M. \& Kindel, A. 2004. Foraging behavior of the White-browed (Basileuterus leucoblepharus) and the Goldencrowned (B. culicivorus) Warblers in a Semidecidual Forest in Southern Brazil. Ornitologia Neotropical 15:5-15.

Mendonça-Lima, A.; Duarte, L. \& Hartz, S. M. 2014. Comparing diversity and dispersal traits of tree communities in plantations and native forests in Southern Brazil. Natureza \& Conservação 12:24-29.

Moermond, T. C. 1979. The influence of habitat structure on Anolis foraging behavior. Behaviour 70:147-167.

PARRISH, J. D. 1995. Effects of needle architecture on warbler habitat selection in a coastal Spruce Forest. Ecology 76:1813-1820.

PILLAR, V. D. 2006. MULTIV: Multivariate exploratory analysis, randomization testing and bootstrapping resampling, user's guide v. 2. 4. Universidade Federal do Rio Grande do Sul, Porto Alegre, Brazil. Available at: <http://ecoqua.ecologia.ufrgs.br/arquivos/ Software/Multiv/MultivManual.pdf > . Accessed at: 04.jan.2013.

PillaR, V. D. \& OrLóCI, L. 1996. On randomization testing in vegetation science: multifactor comparisons of revelé groups. Journal of Vegetation Science 7:585-592.

Pomara, L. Y.; Cooper, R. J. \& Petit, L. J. 2003. Mixed-species flocking and foraging behavior of four neotropical warblers in Panamanian shade coffee fields and forests. Auk 120:1000-1012.

Ramво, B. A. 1951. A imigração da selva higrófila no Rio Grande do Sul. Anais Botânicos do Herbário "Barbosa Rodrigues" 3:55-91.

RAPPOLE, J. H. 1996. The importance of forest for the world's migratory bird species. In: DeGraAf, R. M. \& Miller, R. I. eds. Conservation of faunal diversity in forested landscapes. London, Chapman and Hall, p. 389-406.

Remsen, J. V., JR. \& Robinson, S. K. 1990. A classification scheme for foraging behavior of birds in terrestrial habitats. Studies in Avian Biology 13:144-160.

Ridgely, R. S. \& Tudor, G. 2009. Field guide to the songbirds of South America: the passerines. Austin, University of Texas Press. 736p.

RoBinson, S. K. \& HoLmEs, R. T. 1982. Foraging behavior of forest birds: the relationships among search tactics, diet, and habitat structure. Ecology 63:1918-1931. 
Robinson, S. K. \& Holmes, R. T. 1984. Effects of plant species and foliage structure on the foraging behavior of forest birds. Auk 101:672-684.

Rosário, L. A. M. 1996. As aves em Santa Catarina: distribuição geográfica e meio ambiente. Florianópolis, FATMA. 326p.

SABo, S. R. \& Holmes, R. T. 1983. Foraging niches and the structure of forest bird communities in contrasting montane habitats. Condor 85:121-138.

Santa Catarina. 1986. Atlas de Santa Catarina. Florianópolis, GAPLAN/SUEGI. 173p.

Sick, H. 1997. Ornitologia brasileira. Rio de Janeiro, Nova Fronteira. 912p.

SoARes, E. S. \& ANJos, L. 1999. Efeito da fragmentação florestal sobre aves escaladoras de tronco e galho na região de Londrina, norte do Estado do Paraná, Brasil. Ornitologia Neotropical 10:61-68.

Traylor, M. A., JR. \& Fitzpatrick, J. W. 1982. A survey of the tyrant flycatchers. Living Bird 19:7-45.
Volpato, G. H.; Prado, V. M. \& Anjos, L. 2010. What can tree plantations do for forest birds in fragmented forest landscapes? A case study in southern Brazil. Forest Ecology and Management 260:1156-1163.

WALTHER, B. A. 2002. Grounded ground birds and surfing canopy birds: variation of foraging stratum breadth observed in neotropical forest birds and tested with simulation models using boundary constraints. Auk 119:658-675.

WhELAN, C. J. 2001. Foliage structure influences foraging of insectivorous forest birds: an experimental study. Ecology 82:219-231.

Wunderle, J. M., JR. \& LATTA, S. C. 1998. Avian resource use in Dominican Shade Coffee Plantations. The Wilson Bulletin 110:271-281.

Zurita, G. A.; Rey, N.; Varela, D. M.; Villagra, M. \& BellocQ, M. I. 2006. Conversion of the Atlantic Forest into native and exotic tree plantations: Effects on bird communities from the local and regional perspectives. Forest Ecology and Management 235:164-173. 